\title{
The Influences of Antenatal Care, Postnatal Care and Early Initiation of Breastfeeding on an Exclusive Breastfeeding Pattern in the Working Area of Manukan Kulon Public Health Center at Surabaya City
}

\author{
Azizi Pridasari ${ }^{1}$, Lutfi Agus Salim ${ }^{2}$ \\ ${ }^{1}$ Bachelor Student in Department Biostatistics and Demography, Faculty of Public Health, Universitas Airlangga, \\ Surabaya, Indonesia, ${ }^{2}$ Associate Professor in Department Biostatistics and Demography, Faculty of Public Health, \\ Universitas Airlangga, Surabaya, Indonesia
}

\begin{abstract}
Exclusive breastfeeding is very important for babies to maintain their immune system, brain intelligence, emotion stability and to protect babies from various diseases that are causes of death. Breastfeeding will also benefit the mother, which will reduce blood loss during menstruation, restore maternal weight as before pregnancy, reduce the risk of breast cancer, and uterine cancer. The purpose of this study was to determine the influences of antenatal care, postnatal care and early initiation of breastfeeding on an exclusive breastfeeding pattern. The samples used in this study were mothers who had babies aged 7-12 months in June to August 2018 as many as 48 respondents in the working area of Manukan Kulon Health Center in Surabaya. This study used the descriptive and bivariate analyses. The obtained results were antenatal care $(p=0.001)$, postnatal care $(p=0.002)$ and early initiation of breastfeeding $(p=0,000)$. During pregnancy the majority of mothers make complete antenatal care visits with a frequency of 10 times, antenatal care is very important for mothers, especially the pattern of breastfeeding. In addition to the importance of antenatal care visits, mothers who have given birth and are entering the postnatal care phase are required to make postnatal care visits. Socialization from health workers and the support of closest people are required in order to achieve the exclusive breastfeeding.
\end{abstract}

Keywords: Exclusive Breastfeeding, Early Initiation of Breastfeeding, Antenatal Care, Postnatal Care.

\section{Introduction}

Exclusive breastfeeding is the provision of breast milk that is given to infants without giving any additional food and drinks to the baby until the age of 6 months and given the breastfeeding as early as possible ${ }^{(1)}$. Breast milk as the main food of babies is

\section{Corresponding Author:}

\section{Lutfi Agus Salim}

Associate Professor in Department Biostatistics and Demography, Faculty of Public Health, Universitas Airlangga, Surabaya, Indonesia e-mail: lutfi.as@fkm.unair.ac.id very important because breast milk contains $60 \%$ of the nutritional needs of babies. Breast milk has several benefits including the intelligence of baby's brain, the baby's emotion stability and can protect the baby from various diseases that are causes of death. Breastfeeding will also benefit the mother, which will reduce blood loss during menstruation, restore maternal weight as before pre-pregnancy and reduce the risk of breast cancer and uterine cancer. Although breastfeeding and breast milk are very beneficial, it is estimated that $85 \%$ of mothers in the world do not give an exclusive breastfeeding as recommended by WHO (2002). Many mothers in many countries do not provide exclusive breastfeeding due to various factors such as social, cultural, economic and political $^{(2)}$. 
Breastfeeding can affect the reduction in newborn mortality from the first day of birth by $16 \%$ and will reduce death possibility by $22 \%$ if the newborn is given breast milk within the first hour after birth. In 2012, the 0-5 month's infants received exclusive breastfeeding with the percentage of $41.5 \%$. In 2013, infants who received exclusive breastfeeding were $38 \%$. In 2014, the coverage of exclusive breastfeeding in Indonesia did not meet the strategic plan target of $52.3 \%$ while the target to be achieved was $80 \%$. However, in 2015 , the national target of exclusive breastfeeding was reduced to the amount of $39 \%$ so that the national target was able to be reached.

In 2016, the results of nutrition monitoring in Indonesia showed that newborns received early initiation of breastfeeding with the percentage of $51.9 \%$. The infants who were aged 0-5 months received an exclusive breastfeeding with the percentage of $54 \%$, while infants who were aged 0-6 months get exclusive breastfeeding by $29.5 \%$. On these results, it can be concluded that babies received a complementary food of breastfeeding at the age of 5 months on average.

According to the Isrono study in 2013, mothers who gave exclusive breastfeeding in the working area of Serpong Public Health Center were as much as $14.6 \%{ }^{(3)}$. In conclusion, the information that has been given and obtained were not necessarily going to be implemented properly.

\section{Methodology}

The samples used in this study were mothers who had babies aged 7-12 months in June to August 2018 as many as 48 respondents. The technique used in this study was by carrying out the data retrieval in the working area of Manukan Kulon Public Health Center at Surabaya City by using the simple random sampling formula.

The dependent variable in this study was the pattern of exclusive breastfeeding. Meanwhile, the independent variables in this study were the influence of antenatal care, postnatal care and early initiation of breastfeeding.

Data analyses in this study were using descriptive and bivariate analyses. Descriptive analysis was used to describe the characteristics of each independent and dependent variables. Meanwhile, bivariate analysis was used to see the relationship between each independent and dependent variables using a logistic regression analysis. Through the logistic regression test, the value of $p$ would be obtained, which in this study used a significance level of 0.05 . Research between the two variables was said to be meaningful if it had a value of $p<0,05$ which meant Ho was rejected and H1 was accepted. It was said to be meaningless if it had $p>=0,05$ which meant that Ho was accepted and $\mathrm{H} 1$ was rejected. Bivariate analysis was carried out to select candidates for influential factors.

\section{Results}

Antenatal care is a midwifery service for pregnant women that aims to maintain the health of pregnant women and ensure normal birth can be carried out at least four times during pregnancy to confinement. Antenatal care visits are grouped into 2 groups, namely complete and incomplete antenatal care visits. Research result shows that the majority of respondents made a complete antenatal visit from the beginning of the pregnancy to giving birth with a total of 44 people $(91.6 \%)$. Respondents who had an incomplete antenatal care visit were as many as 4 people (8.4\%) with a frequency of 4 time visits.

Postnatal Care (PNC) is the period after the placenta is born and the period ends when the uterus organs returns to its pre-pregnancy state. At this time, the body is making both physical and psychosocial adjustments to the birth process that starts immediately after the placenta is born until the body can adjust to perfection and ends when the uterine organs return to their pre-pregnancy state which lasts for 6 weeks. Research result shows that all respondents take the postnatal care visit after giving birth, although with different frequency of visits. The most postnatal care visit was 2 times with a percentage of $60.4 \%$, followed by postnatal care visits as much as 3 times by $31.3 \%$ and the least was one time postnatal care visit with a percentage of $8.3 \%$. The percentage was very good because postnatal care visits were suggested to be done at least once after giving a birth.

The coverage of early initiation of breastfeeding among respondents in the working area of Manukan Kulon Public Health Center at Surabaya can be categorized as good, because most respondents initiated early breastfeeding immediately after the baby was born with the percentage of $91.7 \%$ and $8.3 \%$ did not initiate early breastfeeding. 
Table 1. Distribution of Breastfeeding Pattern Based on Ante Natal Care (ANC) Visits

\begin{tabular}{|c|c|c|c|c|c|c|}
\hline \multirow{3}{*}{ ANC Visit } & \multicolumn{4}{|c|}{ Breastfeeding Pattern } & \multirow{2}{*}{\multicolumn{2}{|c|}{ Total }} \\
\hline & \multicolumn{2}{|c|}{ Exclusive } & \multicolumn{2}{|c|}{ Non-Exclusive } & & \\
\hline & $\mathbf{n}$ & $\%$ & $\mathbf{n}$ & $\%$ & $\mathbf{N}$ & $\%$ \\
\hline Complete & 4 & 9,1 & 40 & 90,9 & 44 & 100,0 \\
\hline Incomplete & 0 & 0,0 & 4 & 100,0 & 4 & 100,0 \\
\hline Total & 4 & 8,3 & 44 & 91,7 & 48 & 100,0 \\
\hline
\end{tabular}

Distribution results on the pattern of breastfeeding based on Antenatal Care visit in the table 1 shows that most respondents with complete ANC visits gave breastfeeding with a non-exclusive pattern with a percentage of $90.9 \%$ while respondents who did not routinely make ANC visits gave breastfeeding with a non-exclusively pattern by $100 \%$.

Table 2 Distribution of Breastfeeding Pattern Based on Post Natal Care (PNC) Visit

\begin{tabular}{|c|c|c|c|c|c|c|}
\hline \multirow{3}{*}{ PNC Visit } & \multicolumn{4}{|c|}{ Breastfeeding Pattern } & \multirow{2}{*}{\multicolumn{2}{|c|}{ Total }} \\
\hline & \multicolumn{2}{|c|}{ Exclusive } & \multicolumn{2}{|c|}{ Non-Exclusive } & & \\
\hline & $\mathrm{n}$ & $\%$ & $\mathrm{n}$ & $\%$ & $\mathrm{n}$ & $\%$ \\
\hline 1 Time & 0 & 0,0 & 4 & 100,0 & 4 & 100,0 \\
\hline 2 Time & 4 & 3,18 & 25 & 86,2 & 29 & 100,0 \\
\hline 3 Time & 0 & 0,0 & 15 & 100,0 & 15 & 100,0 \\
\hline Total & 4 & 8,3 & 44 & 91,7 & 48 & 100,0 \\
\hline
\end{tabular}

Based on the results in table 2, the majority of respondents visited Postnatal Care twice with a frequency of 29 respondents. The respondents who visited PNC twice and determined the pattern of nonexclusive breastfeeding had a lower percentage with a total of $86.2 \%$. Meanwhile, the respondents who visited PNC once and three times and determined the pattern of non-exclusive breastfeeding to their babies had a greater percentage by $100 \%$ respectively.

Table 3 Distribution of Breastfeeding Pattern Based on the Early Initiation of Breastfeeding (EIB)

\begin{tabular}{|c|c|c|c|c|c|c|}
\hline \multirow{3}{*}{ EIB } & \multicolumn{4}{|c|}{ Breastfeeding Pattern } & \multirow{2}{*}{\multicolumn{2}{|c|}{ Total }} \\
\hline & \multicolumn{2}{|c|}{ Exclusive } & \multicolumn{2}{|c|}{ Non-Exclusive } & & \\
\hline & $\mathbf{n}$ & $\%$ & $\mathbf{n}$ & $\%$ & $\mathbf{n}$ & $\%$ \\
\hline Yes & 4 & 9,1 & 40 & 90,9 & 44 & 100,0 \\
\hline No & 0 & 0,0 & 4 & 100,0 & 4 & 100,0 \\
\hline Total & 4 & 8,3 & 44 & 91,7 & 48 & 100,0 \\
\hline
\end{tabular}

The pattern of breastfeeding based on Early Initiation of Breastfeeding in table 3 shows that there were more respondents who did the EIB than those who did not. Respondents who did EIB mostly gave non-exclusive breastfeeding to their babies with the percentage of
$90.9 \%$. Meanwhile, the respondents who did not give an EIB tended to give a non-exclusive breastfeeding to their babies with a percentage of $100 \%$. The analysis of the independent and dependent variables by using logistic regression analysis $(\mathrm{a}=0,05)$ are as follows. 
Table 4 Bivariate Analysis of Antenatal Care, Postnatal Care and Early Initiation of Breastfeeding

\begin{tabular}{|l|c|c|}
\hline Variable & Sig & Explanation \\
\hline Antenatal Care & 0,001 & Significant \\
\hline Postnatal Care & 0,002 & Significant \\
\hline $\begin{array}{l}\text { Early Initiation of } \\
\text { Breastfeeding }\end{array}$ & 0,000 & Significant \\
\hline
\end{tabular}

Based on table 4, the logistic regression analysis obtained, there were 3 variables that influenced the pattern of breastfeeding to mothers, namely antenatal care $(p=0,001)$, postnatal care $(p=0,002)$ and early initiation of breastfeeding $(p=0,000)$.

\section{Discussion}

Antenatal Care Factor: Antenatal care is a health service for a mother during her pregnancy which carried out in accordance with established antenatal care standards. The visit of pregnant women to health services is recommended as follows; once in the first quarter, once in the second quarter and at least 2 times in the third quarter ${ }^{(4)}$. Ideally, every woman who is pregnant wants to have a pregnancy check in order to detect abnormalities that exist or will arise in the pregnancy are quickly identified and can be addressed immediately before affecting the pregnancy by conducting antenatal care checks ${ }^{(5)}$.

The results show that the respondents who did a complete antenatal care visit were as much as $91.6 \%$ while the respondents who did not make a complete antenatal visit were $8.4 \%$. The results of the study show that most respondents were aware of the importance of maintaining pregnancy ${ }^{(6)}$.

According to the Indonesian Ministry of Health (2012), ANC visits of pregnant women are influenced by several factors ${ }^{(7)}$. The factors are including internal factors such as parity, mother's age and also external factors such as mother's knowledge, attitudes, socioeconomic conditions, socio-cultural, geographical, information and also the support from both staff and family ${ }^{(8)}$.

The results show that the majority of respondents with a percentage of $91.6 \%$ made a complete ANC visit, the respondents who gave exclusive breastfeeding by $9.1 \%$ and while the respondents who gave non-exclusive breastfeeding were at $90.9 \%$. This study was in line with a research conducted by Suparmi and Ika (2012) which stated that ANC visits affect the increase in the scope of exclusive breastfeeding ${ }^{(9)}$.

Postnatal Care Factor on Breastfeeding Pattern: Postnatal care is a series of treatments performed for postpartum mothers including massages, breast care, oxytocin massage, postpartum spa and so on. Postnatal care is done so that the puerperal mother can pass through the puerperium phase well without any complications ${ }^{(10)}$.

The purpose of the postnatal care visit is to take care of the health of both mother and baby, both physical and psychological, to treat the patient if any complications occur, provide health education regarding self-health care, nutrition, breastfeeding, provide information to the baby and care for healthy babies and providing family planning services ${ }^{(11)}$.

The results show that the respondents who routinely visited postnatal care once were $8.3 \%$, while those who did postnatal care visit twice were $60.4 \%$ and the respondents who visited postnatal care three times amounted to $31.3 \%$. The distribution of PNC visits is positively related to the pattern of breastfeeding. Most respondents with a total of $86.2 \%$ with the frequency of PNC visits as much as twice decided to do the breastfeeding with a non-exclusive pattern.

The results show that postnatal care visits affect the pattern of breastfeeding. This study was in line with the research conducted by Seid et.al (2013) in Bahir Dar City Administration, Northwest Ethiopia which stated that there was a relationship between the amount of PNC visits with the exclusive pattern of breastfeeding ${ }^{(12)}$.

\section{Early Initiation of Breastfeeding (EIB) Factor on} Breastfeeding Pattern: Early Initiation of Breastfeeding (EIB) which stands for early initiation of breastfeeding, is the baby's active effort to suckle within the first hour of birth, both normal and cesarean deliveries. The baby is placed on the mother's abdomen and chest immediately after birth and given the opportunity to start breastfeeding herself or himself by crawling for beasts and letting the baby's skin contact with her mother for an hour. On the first hour, the baby finds his mother's breasts in the beginning of a "life-sustaining between mother and child." The World Health Organization (WHO) recommended early breastfeeding to be initiated within the first hour after the baby is born by placing the baby in the mother's chest as soon as the baby is out of the birth canal ${ }^{(13)}$. 
The results of this study indicate that respondents who did an EIB were as many as $91.7 \%$, while the respondents who did not do the EIB were $8.3 \%$. In conclusion, most mothers have understood the importance of EIB for babies. The analysis shows that EIB has a big influence on the pattern of breastfeeding. This study was in line with the study of Pongtuluran, et.al (2017) who stated that there is a relationship between EIB and exclusive breastfeeding patterns ${ }^{(14)}$.

\section{Conclusion}

During their pregnancy, majority of mothers make complete antenatal care visits with a frequency of 10 times, antenatal care is very important for mothers, especially the pattern of breastfeeding. In addition to the importance of antenatal care visits, mothers who have given birth and are entering the postnatal care phase are required to make postnatal care visits. Most of the mothers did a two times postnatal care visit and the postnatal care visit in this study had a major influence on the pattern of breastfeeding.

The coverage of mothers who initiate breastfeeding early in their babies after birth (EIB) can also be categorized as good. Therefore, the early initiation of breastfeeding has an influence on the pattern of breastfeeding.

Suggestion: For couples who are going to get married are required to take counseling at a public health center or a hospital to educate themselves regarding the preparation that will be done after marriage and after they have children. Counseling can also increase the mother's knowledge, one of which is the importance of breastfeeding for infants. In addition, health workers also provide education on how to treat breast nipples and injured breasts during breastfeeding.

Conflict of Interest: The authors have no conflict of interest with the material presented in this paper

\section{Sources of Funding: None}

Ethical Clearance: None.

\section{References}

1. Lindawati R. Hubungan Pengetahuan, Pendidikan dan Dukungan Keluarga dengan Pemberian ASI Eksklusif. Faletehan Health Journal. 2019;6(1):306.
2. Laksono W. ASI, Menyusui, dan Sadari. Nuha Medika: Yogyakarta. 2010;

3. Anggraeni MF, Herawati S, Mustika DN. Pemberian Asi Eksklusif Berdasarkan Status Bekerja Ibu Yang Memiliki Bayi Usia 6-11 Bulan Di Wilayah Kerja Puskesmas Karangawen 1 Kabupaten Demak. Jurnal Kebidanan [Internet]. 2015;4(1). Available from: https://jurnal.unimus.ac.id/index.php/jur_ bid/article/view/1389

4. Ministry of Health Republic of Indonesia. Profil Kesehatan Indonesia tahun 2014. Jakarta: Kementerian Kesehatan RI. 2015. 1-382 p.

5. Ministry of Health Republic of Indonesia. InfoDATIN : pusat data dan informasi kementerian kesehatan RI: mother's day. Jakarta: Jakarta: Pusat Data dan Informasi Kementerian Kesehatan RI; 2014.

6. Ningsih P. Hubungan Umur, Pengetahuan Dan Dukungan Keluarga Dengan Kunjungan Antenatal Care (Anc)(K4) Ibu Hamil Di Puskesmas Pariaman Tahun 2018. Jurnal Ilmu Keperawatan dan Kebidanan. 2020;11(1):62-9.

7. Direktur Jenderal Bina Kesehatan Masyarakat. Pedoman pelayanan antenatal terpadu. Kementrian Kesehatan. Jakarta; 2012.

8. Kurniawan B. Determinan keberhasilan pemberian air susu ibu eksklusif. Jurnal Kedokteran Brawijaya. 2013;27(4):236-40.

9. Suparmi S, Saptarini I. Determinan Pemberian Asi Eksklusif: Analisis Data Sekunder Survei Demografi Dan Kesehatan Indonesia 2012. Indonesian Journal of Reproductive Health. 2014;5(1):15-21.

10. Mirzaei K, Ghadikolaee S, Mousavi Bazzaz M, Ziaee M. Mother's satisfaction of postpartum care and its relationship with midwifery care at Urban Health Centers, Mashhad, Iran. journal of midwifery and reproductive health. 2016 Oct 21;

11. Manuaba IBG. Ilmu kebidanan, penyakit kandungan dan keluarga berencana. Jakarta: EGC. 2010;15:157.

12. Seid AM, Yesuf ME, Koye DN. Prevalence of Exclusive Breastfeeding Practices and associated factors among mothers in Bahir Dar city, Northwest Ethiopia: a community based crosssectional study. International Breastfeeding Journal [Internet]. 2013;8(1):14. Available from: https:// doi.org/10.1186/1746-4358-8-14 
13. Djamil A, Hermawan NSA, Setiarini N. Hubungan Pelaksanaan Manajemen Laktasi oleh Petugas Kesehatan terhadap ASI Eksklusif pada Ibu Menyusui. Jurnal Kesehatan. 2018;9(1):113-6.
14. Ekaristi P, Kandou GD, Mayulu N. Hubungan Inisiasi Menyusui Dini (Imd) Dengan Pemberian Asi Eksklusif Di Kota Manado. KESMAS. 2017;6(3). 